\title{
Effects of Mastery Learning Instruction on Engineering Students' Writing Skills Development and Motivation
}

\author{
Amare Tesfie Birhan \\ Bahir Dar Institute of Technology
}

\begin{abstract}
Correspondence concerning this article should be addressed to Amare Tesfie Birhan, Department of English Language and Literature, Bahir Dar Institute of Technology, P.O.Box 26. Bahir Dar, Ethiopia. E-mail: amaretesfie@gmail.com
\end{abstract}

\begin{abstract}
This study was aimed to investigate the effects of mastery learning instruction on engineering students' academic writing skills and motivation in an EFL context. The participants were software engineering and computer science first-year students, and they were selected using a multistage sampling technique. Observation, a questionnaire, and pre- and post-tests were employed as data gathering instruments. The research was designed through a time series quasi-experimental research design. The data were analysed through repeated measure ANOVA, independent t-tests, as well as descriptive statistics. The findings indicated that there was a statistical difference between the experimental and the control groups. Hence, students who participated in mastery learning instruction improved their writing skills and achieved better scores in writing skills assessment. Particularly, learners who learned through mastery learning instruction were able to develop paragraphs and essays with clear topic sentences and thesis statements. They also developed paragraphs with proper punctuation and minimized various mechanical errors that were observed during the pre-test. Furthermore, the students who engaged in mastery learning instruction had better levels of motivation. Thus, individualized instruction and continuous feedback helped them improve their engagement in writing activities. Hence, this study calls for more attention to self-paced instruction, regular feedback, assessment, and continuous support in writing classrooms.
\end{abstract}

Keywords: engineering students, mastery learning instruction, motivation, writing skills, zone of proximity development

Writing skill is one of the most significant skills in learning English as a second and foreign language. It is a fundamental language element that helps students improve their language competence, literacy, and develop cognitive skills (Behizadeh \& Engelhard, 2011; Bacha, 2002). Mesfin (2013) also asserts that writing is a very crucial skill for improving learners' thinking and efficiency in the academic world. Particularly, engineering and technology students need this skill to write their projects, reports, and research papers, which helps them become better readers and thinkers and improve their ability to communicate. Above all, according to Prithvi and Caroline (2012), writing is considered a central skill for students in higher education.

However, writing is also one of the most difficult skills to improve (Lazaro, 1996). For instance, Dawit (2013) mentioned that many higher institution students are facing various problems in their attempt to produce simple written texts in the target language.
Furthermore, Abiy (2013) and Alfaki (2015) stated that post-secondary-level students and university students face morphological, syntax, and mechanical difficulties, which are essential to writing.

As many researchers have suggested, how effectively writing skills are learned is highly dependent on the teachers' proper use of instructional techniques and relevant activities. For instance, Dawit (2013) explained how the genre approach helps students write argumentative essays, and Karsak, Fer, and Orhan (2014) mentioned that cooperative and individual web blogs, integrated with writing instruction, enhanced students' writing skills. Similarly, Amoush (2015) reported that brainstorming strategies had many positive effects on improving students' writing performance.

In Ethiopian higher education institutions, engineering and technology students take courses such as communicative English skills, basic writing skills, and research and report writing to use the skills 
for general, academic, and professional purposes, but students are struggling to use the skills in different situations. Many students are unable to pass these courses. While they take quizzes, a midterm, and a final exam, many students must take the final exam again as a supplementary exam.

The first main reason that the students fail is the teachers' method of instruction. From the researcher's observations, most teachers use a holistic/conventional version of classroom instruction that does not consider individual differences, learning styles, or preferences. Accordingly, students who learned writing in this institute had a lack of motivation and lacked the language competence to engage in writing activities (Amare, 2017).

Similarly, writing skills are one of the neglected skills in Ethiopian elementary and high schools; it was also observed that skills such as reading, grammar, and speaking skills are emphasised more than writing. Students have limited opportunities to use the skills inside and outside the classrooms. As a result, many students are not able to master the writing contents properly or write paragraphs and essays effectively.

Thus, it is important to consider instructions that consider students' learning competency differences and their learning difficulties. Although recently there have been researchers who have conducted studies to enhance students' writing, there is limited research that has dealt with the effects of mastery learning instruction to enhance students' writing skills and motivation. Therefore, the current research was conducted to explore the effects of a mastery learning instructional strategy, which considers individual differences, learning styles, and preferences on learners' writing skills and motivation.

\section{Theoretical Foundation of Mastery Learning Instruction}

This instruction was first formally proposed by Benjamin Bloom (1968) with the aim of minimizing students' knowledge gaps. According to Guskey (2007), Bloom observed that having little variation in the instruction could not make students achieve equally with those who were different in background, learning style, motivation, school context, etc. According to this type of instruction, mass instruction does not make students equally competent. Thus, this instruction proposed that teachers have the potential to minimize students' differences and gaps (Shafie, Shahdan, \& Liew, 2010; Guskey, 2007; Zimmerman \& Dibenedetto, 2008) through more variation in their teaching and applying active teaching strategies.

Researchers mentioned that students' academic achievement can be affected by many affective factors such as gender, age, motivation, school context, student attitude, and behaviour (Akey, 2006; Voyles, 2011; Welch-Deal, 2003). In addition, research conducted by CERI ${ }^{1}$, Dunlosky, Rawson, Marsha, Nathan and Willingham (2013), and Boersma (2008) also mentioned other factors like collaborative work, formative assessment, students learning styles, and effective learning techniques that contribute to the academic success of students. Similarly, Amiruddin and Zainudin (2015) argued that the lack of effective teaching and learning contributes to lower student academic achievement.

Accordingly, the concept of mastery learning is to maximize students' academic achievement. The instruction is practiced by considering the individual differences that affect students' academic achievements (Guskey, 2007) and makes many students in schools or classrooms effective learners. Guskey (2007, p. 15) added that "teachers who use mastery learning instruction provide frequent and specific feedback on their learning progress through regular, formative classroom assessments."

Likewise, researchers who conducted research on mastery learning instruction proved that it improves classroom instruction and students' academic achievement (Sadeghi \& Sadeghi, 2012; Guskey, 2007; Wambugu \& Changeiywo, 2008; Wong \& Kang, 2012). In spite of this, researchers such as Horton (1979) argued about the effectiveness of mastery learning instruction in the classroom. Horton claimed that it is difficult to use mastery learning instruction as it is not readily adaptable to regular classes.

However, mastery learning instruction has a flexible approach that can be applied in virtually any classroom to help almost any student master what they are taught. Carroll's 1989 study (as cited in Shafie, Shahdan, \& Liew, 2010) asserts that all learners have the potential to learn over different periods of time to achieve a particular subject matter. Kazu, Kazu, and Ozdemir (2005, p. 234) also mention "mastery learning aimed at providing appropriate learning environments by considering the individual differences of the students so that they do not hinder the target learning activity." It is believed that learners achieve the same level of content mastery at different time intervals (John, Ravi, \& Ananthasayanam, 2009).

Theoretically, this instruction is related to social constructivist and mediation theories. Learners acquire the required skills and knowledge through the support of their teachers and peers, and the students who understand the content better can

1 CERI. (2008). Assessment for learning formative assessment. Organization for economic co-operation and development. Retrieved from https://www.oecd.org/site/educeri21st/40600533. pdf 
help other students continuously until they achieve the content objectives.

Furthermore, this instruction blends continuous instruction and assessment. Teachers provide frequent and specific interventions on their learning progress, typically through the use of regular, continuous classroom assessments (Guskey, 2005), and learners do not move on to other sections until they have attained the intended objectives of the current section (Estaji \& Fassihi, 2016).

\section{Formative Assessment in Mastery Learning Instruction}

Formative or continuous assessment is one of the pioneer aspects of mastery learning instruction, whereby students are assessed formatively to follow up on their mastery level and to give continuous feedback. According to Prithvi and Caroline (2012), formative assessment is crucial for helping them improve their writing skills. Likewise Guskey (2010, p. 4) stressed that "in mastery learning, assessments are not a one-shot, do-or-die experience; instead they are part of an on-going effort to help students learn.”

Furthermore, according to Wiliam and Thompson 2007's idea cited in (Black and Wiliam, 2009) it helps to clarify and share learning intentions and criteria for success, engineer effective classroom discussions and other learning tasks that elicit evidence of student understanding, provide feedback that moves forward, activate students as instructional resources for one another, and activate students as the owners of their learning. These help learns to engage actively in the lesson.

Peer feedback is another important strategy that is employed in writing classrooms to enhance students' engagement and to support the learning process. Cho and MacArthur (2010) stated that peer feedback is very crucial and rich comments should be received from multiple peers.

According to social constructivist theory, learning takes place through interactions with parents, peers, teachers, and others. Language learning relies on meaningful social interactions within social and cognitive support systems for helping learners improve their language and conceptual understanding (Dunap \& Wiseman, 2007 cited in Betegiorgis \& Abiy, 2015). Abiy (2005) also explained that in foreign language contexts teachers and better-performing students mediate their peers' learning. As a result, students can master the given content via frequent assessment and peer and teacher support.

\section{Mastery Instruction and Students Motivation}

As discussed above, there are many affective factors that can influence or maximize students learning in the academic context. Among these factors, motivation is the main factor that affects students' academic achievements. According to Wieman (2013), motivation is the most important element of learning that plays a key part in improving students' academic achievement (Peklaj \& Levpuscek, 2006).

Thus, in mastery learning instruction, students engage in the classroom lesson and get assistance from both the teacher and their peers. This creates motivation to have active engagement in the lessons they learn. The instruction also helps learners to be motivated in the lesson by changing their thinking and interest towards learning (Ozden, 2008; Kazu, Kazu, \& Ozdemir 2005). Likewise, Guskey (2010) affirmed that mastery learning instruction is a powerful motivational tool by giving students continuous chances to succeed. Guskey added that these activities give students exciting opportunities to enlarge and develop their learning.

Williams and Burden (1997, p. 120) stressed that "motivation is a state of cognitive and emotional arousal which leads to a conscious decision to act and which gives rise to a period of sustained intellectual and/or physical effort in order to attain a previously set goal (goals)." Students' motivation is enhanced through their sense of agency, feeling mastery, and control over the learning activity as well as their interests (Lo \& Hyland, 2007). Hence, students' motivation and their engagement in writing activities are very interrelated. Accordingly, motivation plays a very paramount role to the development of students' writing as it is a driving force for writing in a meaningful way (Hamidun, Hashim, \& Othman, 2012). Mackiewicz and Thompson (2013) also asserted that motivation is the drive to actively invest in sustained effort toward a goal, which is essential for writing improvement. They added that it directs attention toward particular tasks and increases both effort and persistency.

Therefore, this research hypothesised that students need self-paced assistance and instruction accompanied by interactive feedback and formative assessment to consider their writing skills proficiency differences, and it was assumed that it fostered students' writing skills and motivation. As a result, the main objective of this research was to explore pedagogical approaches that consider each student's language competency, exposure differences, and learning preferences. Thus, the objective of this study was to examine the effects of mastery learning instruction on students' writing skills and motivation, and it was aimed to answer the following research questions: 
- What are the effects of mastery learning instruction on students' writing skills development?

- What are the effects of mastery learning instruction on students' motivation?

\section{Materials and Methods}

\section{Design}

This paper reports the effects of mastery learning instruction on students' writing skills development and their motivation. Hence, the research was conducted in basic writing classes, and both qualitative and quantitative data were used. The research considered two groups (experimental and control). The experimental group had eight weeks of intervention with differentiated learning approaches; whereas, the control group was instructed through conventional approaches. Students' writing skills proficiency, levels of engagement, background, and motivation were considered during the instruction process. Tests were also administered repeatedly. Thus, the research was designed through a time series quasi-experimental research design.

\section{Participants and Sample of the Study}

The participants of study were first-year students who enrolled in Bahir Dar Institute of Technology, Bahir Dar University in the 2016/2017 academic year. In the institution, there were 28 sections, including first-year students who were assigned in different departments. Therefore, the researcher selected two sections (one section from software engineering and one section from computer science) through a multistage sampling technique. Hence, 53 software engineering students were assigned as the experimental group and 52 computer science students were assigned as the control group.

\section{Instruments}

In order to investigate the effects of mastery learning instruction to enhance students' writing skills, pre and post-tests, a questionnaire, and observation instruments were used.

Tests were the major instrument used by the researcher. The researcher administered a pre-test and a post-test for both the control and experimental groups. In Ethiopia, there is no standardized test that can measure students' writing proficiency. The tests were teacher made and the standard and content validity of the tests were checked by English language and literature instructors. The instructors who checked the validity are experts who hold $\mathrm{PhD}$ degrees in the field and have been teaching the course for more than 20 years. Hence, some items of the instruments were changed and adjusted based on the comments and results of the pilot study.

Accordingly, the students who were assigned to the experimental group were assessed continuously and repeatedly until they achieved the course objectives; whereas, the control group was assessed according to the assessment assigned (12\% quiz, 11\% paragraph writing, $12 \%$ essay writing, $25 \%$ midterm exam, and $40 \%$ final exam) by the department. The students' continuous results in each assessment were used to triangulate the end result differences between the control and the experimental groups.

The questionnaire was the other main instrument that the researcher employed to collect the data with regard to the level of student motivation attributed to mastery learning instruction. Students' motivation was measured using criteria such as self-efficacy, active learning strategies, learning environment stimulation, and performance goals.

The questionnaire was adopted from Tuan, Chin, and Shieh (2005), and the items addressed the level and reasons of motivation. Among the participants, 35 computer science and 44 software engineering students filled out and submitted the questionnaire to the researcher.

The researcher also observed classroom practices; the purpose of the observation was to assess regular behavioural changes in students. Particularly, the observation checklists addressed classroom practices (participation in doing classwork and homework, engagement in group and pair discussions, and participation in asking and answering questions), punctuality, regular class attendance, and tutorial and regular class attendance. This was done using open-ended items and was carried out only with the experimental group, which was then used to triangulate what students responded to in the questionnaire data.

\section{Procedure}

The purpose of this research was to assess the effects of mastery learning instruction on students' writing skills and motivation in Bahir Dar Institute of Technology, Bahir Dar University. After choosing the study groups, the researcher assigned the two selected groups as control and experimental groups. Then, the researcher had discussions with the experimental group on the new instruction technique. To engage students in repetitive tasks and activities during the intervention, it was mandatory to get consent from the participants.

The pre-test was prepared and administered to 
both groups before the intervention took place. The test validity was checked by two $\mathrm{PhD}$ experts in the Department of English Language and Literature. The objectives, course contents, and assessment techniques were also clarified to students. Therefore, the students learned each section and assessed repeatedly. The students had various amount of contact time until they achieved the specific section objectives. In addition, the students discussed various activities in groups. These were done based on Guskey's (2007) mastery learning instruction process.

Therefore, learners who participated in mastery learning instruction had been given various enrichment activities, correctives, and formative assessment. The students who participated in these kinds of additional activities were students who scored $80 \%$ and below on their assessment. However, students who scored above $80 \%$ were considered to have developed the required level of competence in the course.

Specifically, the lessons that students participated in were effective sentence construction, effective paragraph writing, techniques for paragraph development, and essay writing. They wrote paragraphs and essays after clear conceptual clarifications were given by the teacher. Likewise, students participated in peer feedback; it focused on constructing effective sentences, paragraphs, and essays; developing unified and coherent writing discourse; developing topic and thesis statements; mechanical errors such as punctuation marks; capitalization; and spelling. Thus, students exchanged qualitative feedback using the above criteria with the aim of maximizing their engagement and helping each other's learning. The instructor's role was facilitating and mentoring the peer feedback process, instructing them on how to rewrite their paragraphs and essays, giving feedback on their texts, and marking their paper after final revisions were made by students. This helped the instructor observe the differences between the first draft and the final draft of the texts.

Finally, the post-testwas prepared and administered. The validity of the post-test was checked by the same procedure as the pre-test. Then, the experimental and control groups' final $(100 \%)$ results were input into the students' information management system (SIMS). Their final results were used to compute the statistical differences between the control and the experiment groups. Furthermore, the questionnaire passed through a dual validation process. Hence, it was checked by TEFL PhD candidates and Bahir Dar University, Bahir Dar Institute of Technology instructors. The Cronbach alpha was found to be 0.74 , which indicates that the questionnaire was reliable.

\section{Measures}

Data gathered from the tests and the questionnaires were analyzed using SPSS version 20. Independent sample t-tests, descriptive statistics, and repeated measure analysis of variances (ANOVA) were used to compute the data. Thus, the data obtained from the questionnaire and students' pre and post results were analyzed through independent t-tests, and the experimental group assessment continuous results were computed through repeated measure ANOVA. Lastly, the data obtained from classroom observations was analyzed qualitatively.

\section{Results}

The data which were gathered by quantitative and qualitative gathering tools were analyzed and presented below thematically.

\section{Students' Writing Skills Improvement}

In order to assess students' mastery in writing skills, descriptive statistics were run. Accordingly, Table 1 below shows that both the experimental and control groups had similar writing proficiency in the pre-test. The experimental group had a mean score 36.35; whereas, the control group had a 32.94 mean score. Even if it seemed that the students had some discrepancy, the difference they had was not significant. This indicates the students had similar levels of understanding or skill before the intervention.

However, the intervention brought a significant difference between the control and the experimental groups in the post-test. The mastery group showed more improvement in their academic writing skills and writing score.

As seen in Table 1, a 58.17 mean score was observed on the experimental group post-test, and the control group's post-test mean score value was 45.05. Therefore, the data revealed that although both groups of students improved, the experimental group

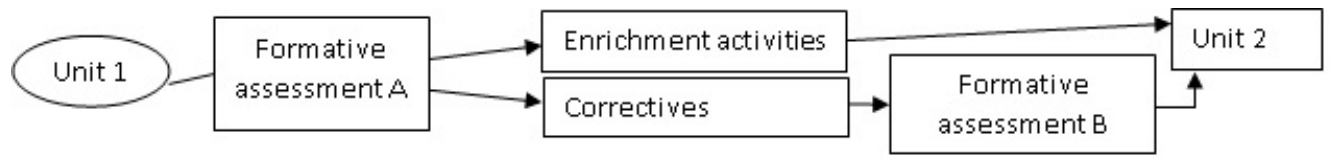

Figure 1. The mastery learning instruction process (Guskey, 2007, p. 14). 
showed greater improvement.

In addition, an independent t-test was run to see the final result's statistical difference between the control and the experimental groups.

Table 2 also reveals that students who participated in mastery learning instruction outperformed in their writing skills and academic writing proficiency. The independent $\mathrm{t}$-test indicates that there was a statistically significant difference between the experimental group and the control group $(\mathrm{t}=4.417$, $\mathrm{df}=103, \mathrm{P}<.05$ ).

As a result, students who engaged in continuous assessment as well as peer and teacher feedback improved their writing skills. According to Bloom's (1971, 1976, and 1984) studies cited in Guskey (2010), although students vary widely in their learning, if teachers are able to provide the necessary time and use appropriate learning conditions, students can reach a high level of achievement. Accordingly, the data showed that mastery learning instruction helped students to improve their writing skills in an EFL context.

Thus, mastery learning instruction could be one of the best forms of instructions to give learners comprehensive input, especially when they have limited opportunities to practice the target language outside the classroom; similarly, the instruction can help them be more engaged in the classroom and achieve the course content objectives.

In the same way, a repeated measure ANOVA was run to determine the mean statistical differences among the time series results of the experimental group (mastery learning instruction students). The assessments were administered to see if there was an improvement in students' results with more frequent (time series) assessment.

The data in Table $3(\mathrm{~F}=42.960, \mathrm{df}=3$, and $\mathrm{P}<.05)$ confirmed that students improved their writing scores using different assessments. The students used good diction, sentences structure, and mechanics, and they were also able to develop good topic sentences, thesis statements, and supportive ideas when they wrote different paragraphs and essays repeatedly. These are observed as the result of comprehensive input, continuous support, and feedback. Hence, long-term and regular assessment, peer instruction, and support can help students earn a better grade and improve their writing skills. It can also give them a chance to identify and fill in their gaps.

\section{Students' Motivation Towards Learning Writing Skills}

The independent t-test was run to compare motivation between students who learned using mastery learning instruction and students who learned via holistic instruction to motivate them in basic writing skills classes. The students' level of motivation was measured by four measurement criteria: self-efficacy, active learning strategies, learning environment stimulation, and students' performance goals.

Table 4 shows that students who undertook mastery learning instruction had better motivation levels than students who learned via the holistic/conventional approach. These differences were observed in students' participation in their writing classes as well. Particularly, the experimental group had better levels

Table 1

Descriptive statistics of the experimental and the control groups

\begin{tabular}{llllcc}
\hline Participants & & $\mathrm{N}$ & Mean & Std. Deviation & Std. Error Mean \\
\hline Experimental group & Pre-test & 52 & 36.35 & 7.162 & .993 \\
& Post-test & 52 & 58.17 & 11.982 & 1.662 \\
Control group & Pre-test & 53 & 32.94 & 7.533 & 1.662 \\
& Post-test & 53 & 45.04 & 17.860 & 2.453 \\
\hline
\end{tabular}

Table 2

Independent $t$-test of the experimental and control groups

\begin{tabular}{llcccccc}
\hline & \multicolumn{1}{c}{$\mathrm{F}$} & Sig. & $\mathrm{t}$ & $\mathrm{df}$. & Sig. (2-tailed) & Std. Error & Diff \\
\hline \multirow{2}{*}{ Total results } & Equal variance assumed & 10.526 & .002 & 4.417 & 103 & .000 & 2.974 \\
& Equal variance not assumed & & & 4.433 & 91.103 & .000 & 2.963 \\
\hline
\end{tabular}

Table 3

Repeated measure ANOVA within-subjects

\begin{tabular}{llcccc}
\hline Source & & df & Mean Square & F & Sig. \\
\hline factor1 & Sphericity Assumed & 3 & 135.641 & 42.960 & .000 \\
\hline
\end{tabular}


of self-efficacy ( $\mathrm{t}=3.209$, MD.3328 and $\mathrm{P}<.05)$. This made learners participate more actively in writing skill activities. Several researchers (Chang \& Chien, 2015; Dogan, 2015; Kanaparan, Cullen, \& Mason, 2017) explained that self-efficacy is highly correlated with learners' engagement and academic achievement. Therefore, students who learned via mastery learning instruction had better motivational levels than the control group.

In addition, the experimental group (mastery learning instruction group) had better active learning participation. Students who participated in mastery learning instruction participated more actively in different active learning strategies $(t=2.085$, MD.3188, $\mathrm{P}<0.25)$. Hence, students played an active role in improving their skills and they engaged more in the writing lessons, and this made students more motivated in classroom. Soltanzadeh, Hashemi, and Shahi (2013) stated that active engagement by the students leads to improvement in learners' academic achievement. Similarly, a marked difference was observed in learning environment stimulations. Tuan, Chin, and Shieh (2005) stressed that learning environment elements such as students, teachers, curriculum, and classroom influenced learners' motivation. Accordingly, it was observed that students who learned through mastery instruction were highly motivated ( $\mathrm{t}=9.5, \mathrm{MD} 1.39$ and $\mathrm{P}<.05)$.

The other students' motivation indicator was performance goals. When students wanted to solve their writing skills problems, they were more likely to be motivated to participate in each and every activity. This helped increase learners' engagement in order to achieve their learning goals and to meet the course and section objectives using the skills in their professional and academic contexts.

In addition to the questionnaire data mentioned above, classroom instruction was observed in order to triangulate and prove student motivation, and it was shown that students were highly engaged and participated during classroom instruction Many students actually changed their views towards improving writing skills, or now believed that it was possible to improve writing skills if they continuously practiced, assessed, and supported each other.

Furthermore, the majority of students participated in tutorial classes more actively than regular class and they tried to fill their knowledge gaps from their colleagues and their teacher, and were highly engaged in the writing activities. Generally, the above data indicated that mastery learning instruction is one of the favoured methods of instruction to enhance engineering and technology students' writing skills and motivate them to engage in various writing activities in EFL classrooms.

\section{Discussion}

Writing is one of the most significant skills in students' academic context and it requires systematic instruction and mastery learning experiences. Consequently, the aim of this research was to investigate the effects of mastery learning instruction on students' writing skills and motivation. The data obtained from the questionnaire and tests were discussed through independent sample t-test, repeated measure ANOVA, and descriptive statistics.

Particularly, the data that showed students who learned through mastery learning instruction improved their writing skills, $\mathrm{t}(103)=4.417, \mathrm{p}<.05$, and the preand post-test showed sizeable differences between the control and the experimental groups. Likewise, the experimental group showed better improvement in the post-test than the pre-test (mean $=36.35$ in the pretest and mean $=58.17$ in the post-test). This indicated that self-paced mastery learning instruction helped learners improve their writing skills and motivation.

This finding agrees with similar research by Amiruddin and Zainudin (2015), Kazu, Kazu, and Ozdemir (2005), Gokalp (2016) and Udo and Udofia (2014). These researchers concluded that the instruction was effective for successful students

Table 4

Comparison of mastery instruction learners and holistic instruction learners' motivation

\begin{tabular}{|c|c|c|c|c|c|c|}
\hline Items & Groups & $\mathrm{N}$ & Mean & Mean Difference & $\mathrm{t}$ & Sig (2 tailed) \\
\hline \multirow[t]{2}{*}{ Self-efficacy of students } & Experimental group & 44 & 3.545 & .3328 & 3.209 & .002 \\
\hline & Control group & 35 & 3.213 & & & \\
\hline \multirow[t]{2}{*}{ Active learning strategies } & Experimental group & 44 & 4.2015 & .3188 & 2.085 & .040 \\
\hline & Control group & 35 & 3.886 & & & \\
\hline \multirow{2}{*}{$\begin{array}{l}\text { Learning environment } \\
\text { stimulation }\end{array}$} & Experimental group & 44 & 3.962 & 1.3193 & 9.500 & .000 \\
\hline & Control group & 35 & 2.643 & & & \\
\hline \multirow[t]{2}{*}{ Performance goals } & Experimental group & 44 & 4.282 & .6825 & 4.101 & .000 \\
\hline & Control group & 35 & 3.600 & & & \\
\hline
\end{tabular}


learning, knowledge acquisition, and academic achievement, and Kulik, Kulik, and Bangert-Drowns (1990) proved in their meta-analysis that the instruction had a positive effect on examination performance. Furthermore, Hill-Miller (2011) reported similar findings that mastery learning instruction improved students' academic achievement.

Although researchers such as Horton (1979) argued that it is difficult to apply mastery learning instruction within a fixed time schedule and with different teaching goals, but this research found that mastery learning instruction principles such as individualized instruction and progress monitoring through formative assessment and feedback helped students improve their writing skills. The instruction combined self-paced learning strategies, peer feedback, and formative assessment to achieve the intended course objectives. Similarly, research such as Barone (1978) also mentioned that it is possible to teach writing and reading skills through the mastery learning model.

Moreover, learners could develop their learning through mediation and the zone of proximal development when students were assisted in their learning by their peers and teacher (Amineh \& Asl, 2015). Hence, the students who participated in mastery learning instruction participated in peer feedback, corrective procedures, and formative assessment, and these helped them enhance their writing skills results. Here, researchers such as Gamlem and Smith (2013) and Titova and Samoylenko (2017) reported that feedback and formative assessment are essential for learning and teaching. Students develop the positive perception that they can do better when they get support from their classmates and they engage actively with the designed objectives.

Furthermore, researchers (Amiruddin \& Zainudin, 2015; Zimmerman \& Dibenedetto, 2008; Ozden, 2008) have reported that mastery learning instruction motivates students through an encouraging environment and appropriate teaching methods. Similarly, this research showed that students who were taught via mastery learning instruction were highly motivated to participate in learning writing skills. Hence, proper mediation by considering individual differences and language competence are very crucial for enhancing learners' motivation and to help them engage more in writing activities.

\section{Conclusion}

The differentiated instruction approach that was proposed in this study had a great impact on students' writing skills development. The research showed that this form of instruction helped learners maximize their writing skills through self-paced learning, mediation, formative assessment, and differentiated instruction. It also confirmed that the instruction was very important for considering students who had less writing skills exposure, competence, and engagement. Particularly, students who engaged in mastery learning instruction improved both their writing skills and their motivation.

Hence, students developed unified and coherent texts and were able to write paragraphs and essays with a clear thesis statement and complete sentences; the topic sentences and the supportive details were also consistent. Furthermore, students used various cohesive devices and transitional markers, which made their written discourses interesting to read and easier to comprehend.

Furthermore, the study proved that students who enrolled in this instruction outperformed the others in the final written assessment. Classroom activities like teacher and peer feedback practices, gap filling instruction, and continuous assessment highly motivated the students to engage in the lesson, acquire the desired skills, and earn a better grade.

Accordingly, the findings of this research haveawider implication for teachers and students. Particularly, it implied that mastery learning instruction helps students acquire high-level competency in writing skills. It also helps learners assess each other's learning and achievement. Furthermore, the research implied that this type of instruction helps encourage students to participate in activities and achieve the course objectives. Thus, the researcher recommends that English language teachers adopt mastery learning instruction and interactive assessment to enhance their students' writing ability. Teachers should also encourage students to get feedback from their peers as well as the teacher.

According to Zimmerman and Dibenedetto (2008), all students can learn as long as they have sufficient time. Thus, this research indicates that teachers have to give enough time to mediate students learning and assist them to master the course contents. Similarly, it suggests to students that they need to use different mastery learning instruction strategies in order to improve their language learning in general and their writing competence in particular.

Finally, since the researcher's conclusions were based on both subjective and objective data, the research has some limitations. First, the numbers of participants were small and focused on one (computing technology) department. Accordingly, these students' results may not represent all of the students who enrolled in the engineering and technology institute during that academic year. Additionally, the data compared the control and the experimental groups' writing skills and motivation, and it was difficult to 
control other variables that may have contributed to the students' writing skills improvement outside the classroom. It was also difficult to observe students' motivation and engagement in writing skills other than through the classroom practice.

Hence, further research needs to be conducted on mastery learning instruction involving larger samples and including other departments' students to add depth to the literature on teaching writing skills through mastery learning.

\section{References}

Abiy, Y. (2005). Effects of teacher mediation on students' conceptions and approaches to reading (Unpublished $\mathrm{PhD}$ dissertation). Addis Ababa University, Addis Ababa, Ethiopia.

Abiy, Y. (2013). High school English teachers' and Students' perceptions, attitudes and actual practices of continuous assessment. Global Journal of Teacher Education, 1(1), 112-121.

Akey, T. M. (2006). School context, student attitudes and behavior, and academic achievements: Building knowledge to improve social policy. Retrieved from http://dev.mdrc.org/sites/default/files/full_519.pdf

Alfaki,I.M. (2015). University students' English writing problems: Diagnosis and remedy. International Journal of English Language Teaching, 3(3), 40-52.

Amineh, R. J. \& Asl, H. D. (2015). Review of constructivism and social constructivism. Journal of Social Sciences, Literature and Languages, 1(1), 9-16.

Amare, T. (2017) Teachers cognition on process genre approach and the practice of teaching writing skills in EFL context. Journal of English for specific world, 54(9), 1-17.

Amiruddin, M. H., \& Zainudin, F. L. (2015). The effects of a mastery learning strategy on knowledge acquisition among aboriginal students: An experimental approach. International Journal of Vocational Education and Training Research, 1(2), 22-26.

Amoush, H. K. (2015). The impact of employing brainstorming strategy on improving writing performance of English major students at Balqa Applied University in Jordan. Journal of Education and Practice, 6(35), 88-92.

Bacha, N. N. (2002). Developing learners' academic writing skills in higher education: A study for educational reform. Language education, 16(3), 163173.

Barone, T. E. (1978). Reading, writing and mastery learning: Are they compatible? In Association for supervision and curriculum development. Retrieved from www.ascd.org/ASCD/pdf/journals/ed_lead/ el 197812

Behizadeh, N., \& Engelhard, G. (2011). Historical view of the influences of measurement and writing theories on the practice of writing assessment in the United States. Assessing writing, 16, 189-211. doi:10.1016/j.asw.2011.03.001

Betegiorgis, M., \& Abiy Y. (2015). Fidelity of peer mediation and its role in improving students' oral English communicative English. Science, Technology and Arts Research Journal, 4(1), 203-214.

Black, P., \& Wiliam, D. (2009). Developing the theory of formative assessment. Educational Assessment, Evaluation and Accountability, 21(1), 5-31.

Boersma, E. (2008). Ethiopian instructors' experience with accommodating EFL students' learning (Unpublished $\mathrm{PhD}$ dissertation). Oklahoma State University, Oklahoma, USA

Chang, D., \& Chien, W. (2015). Determining the relationship between academic self-efficacy and student engagement by meta-analysis. In $2^{\text {nd }}$ International Conference on Education Reform and Modern Management (ERMM 2015) (pp. 142-145). Hong Kong, China: Atlantis Press. Retrieved from https://www.atlantis-press.com/article/20861/pdf

Cho, K., \& MacArthur, C. (2010). Student revision with peer and expert reviewing. Learning and Instruction, 20, 328-338.

Dawit, A. (2013). Enhancing students' writing skills through the genre approach. International Journal of English and Literature, 4(5), 242-248.

Dogan, U. (2015). Student engagement, academic selfefficacy and academic motivation as predictors of academic performance. Anthropologist, 20(3), 553561.

Dunlosky, J., Rawson, K. A., Marsh, E. J., Nathan, M. J., \& Willingham, D. T. (2013). Improving students' learning with effective learning techniques: Promising directions from cognitive and educational psychology. Psychological Science in the Public Interest, 14(1), 4-58.

Estaji, M., \& Fassihi, S. (2016). On the relationship between the implementation of formative assessment strategies and Iranian EFL teachers' self-efficacy: Do gender and experience make a difference? Journal of English Language Teaching and Learning, 8(18), 65-86.

Gamlem, S. M., \& Smith, K. (2013). Student perceptions of classroom feedback. Assessment in Education: Principles, Policy \& Practice, 20(2), 150-169.

Gokalp, M. (2013). The effects of students' learning styles to their academic success. Journal of Creative Education, 4(10), 627-632.

Guskey, T. R. (2005). Formative classroom assessment and Benjamin S. Bloom: Theory, Research and Implication (Unpublished $\mathrm{PhD}$ dissertation). 
University of Kentucky, Lexington, USA.

Guskey, T. R. (2007). Closing achievement gaps: Revisiting Benjamin S. Bloom's learning for mastery. Journal of Advanced Academics, 19(1), 8-31.

Guskey, T. R. (2010). Lessons of mastery learning. Educational Leadership, 68(2), 52-57.

Hamidun, N., Hashim, S. H., \& Othman, N. F. (2012). Enhancing students' motivation by providing feedback on writing: The case of international students from Thailand. International Journal of Social Science and Humanity, 2(6), 591-594.

Hill-Miller, P. L. (2011). Different approach, different results: A study of mastery learning instruction in a developmental reading class at an urban community college (Unpublished PhD Dissertation). University of North Carolina at Charlotte, North Carolina, USA.

Horton, L. (1979, November). Mastery learning: Sound in theory, but... Educational Leadership. Retrieved from http://www.ascd.org/ASCD/pdf/journals/ed_ lead/el_197911_horton.pdf

John, S., Ravi, R., \&Ananthasayanam, R. (2009). Mastery learning through individualized instruction: A reinforcement strategy. I-Manager's Journal on School Educational Technology, 4(4), 46-49. Retrieved from http://www.imanagerpublications. com/article/533/

Kanaparan, G., Cullen, R., \& Mason, D. (2017). Effect of self-efficacy and emotional engagement on introductory programming students. In $28^{\text {th }}$ Australasian Conference on Information Systems (pp. 1-11). Hobart, Australia: Tasmania.

Karsak, O. G., Fer, S., \& Orhan, F. (2014). The effects of using cooperative and individual Weblog to enhance writing performance. Journal of Educational Technology and Society, 17(4), 229-241.

Kazu, I. Y., Kazu, H., \& Ozdemir, O. (2005). The effects of mastery learning model on the success of the students who attended "Usage of Basic Information Technologies” Course. Journal of Educational Technology and Society, 8(4), 233-243.

Kim, J., \& Kim, Y. (2005). Teaching Korean university writing class: Balancing the process and the genre approach. Asian EFL Journal, 7(2), 1-15.

Kulik, C. C., Kulik, J. A., \& Bangert-Drowns, R. L. (1990). Effectiveness of mastery learning programs: A meta-analysis. Review of Educational Research, 60(2), 265-299.

Lazaro, A. (1996). Teaching and assessing writing skills: Acquisition and assessment of communicative skills. Retrieved from http:// citeseerx.ist.psu.edu/viewdoc/download? doi=10.1.1.852.8196\&rep=rep $1 \&$ type $=$ pdf

Lo, J., \& Hyland, F. (2007). Enhancing students' engagement and motivation in writing: The case of primary students in Hong Kong. Journal of Second
Language Writing, 16, 219-237.

Mackiewicz, J., \& Thompson, I. (2013). Motivational scaffolding, politeness, and writing centre tutoring. The Writing Center Journal, 33(1), 38-73.

Mesfin, A. (2013). An exploratory study on the implementation of the process approach to the teaching/learning of the course Basic Writing Skill: The case of Hawassa University (Unpublished PhD Dissertation). Addis Ababa University, Addis Ababa, Ethiopia.

Ozden, M. (2008). Improving science and technology education achievement using mastery learning model. Journal of World applied Science, 5(1), 62-67.

Peklaj, C., \& Levpuscek, M. P. (2006). Students' motivation and academic success in relation to the quality of individual and collaborative work during a course educational psychology. In $31^{\text {st }}$ Association for Teacher Education in Europe (pp. 147-161). Bath, UK: Bath Spa University Press.

Prithvi, S., \& Caroline, C. (2012). Dynamic assessment, tutor mediation and academic writing development. Assessing writing, 17, 55-70.

Sadeghi, A., \& Sadeghi, A. (2011). Relevance of mastery learning (ML) in teaching of English (Case study of the University of Gulian, Iran). Creative Education, 3(1), 41-44.

Shafie, N., Shahdan, T. N. T., \& Liew, M. S. (2010). Mastery learning assessment model (MLAM) in teaching and learning mathematics. In Procedia Social and Behavioral Sciences, 8, 294-298. doi:10.1016/j.sbspro.2010.12.040

Soltanzadeh, L., Hashemi, S., \& Shahi, S. (2013). The effect of active learning on academic achievement motivation in high school students. Archives of Applied Science Research, 5(6), 127-131.

Titova, S., \& Samoylenko, O. (2017). An enquiry-based approach to develop language and skills in mobilesupported classrooms. Journal of Language and Education, 3(3), 39-40. doi:10.17323/2411-73902017-3-3-39-49

Tuan, L. H., Chin, C. C., \& Shieh, H. S. (2005). The development of a questionnaire to measure students' motivation towards science learning. International Journal of science education, 27(6), 639-654.

Udo, M. E., \& Udofia, T. M. (2014). Effects of mastery learning strategy on students' achievement in symbols, formulae and equations in chemistry. Journal of Educational Research and Reviews, 2(3), 28-35.

Voyles, M. J. (2011). Students' academic success as related to students' age and gender (Unpublished $\mathrm{PhD}$ dissertation). The University of Tennessee at Chattanooga, Tennessee, USA.

Wambugu, P. W., \& Changeiywo, J. M. (2008). Effects of mastery learning approach on secondary school 


\section{AMARE TESFIE BIRHAN}

students' physics achievement. Eurasia Journal of Mathematics and Technology Education, 4(3), 293302.

Welch-Deal, M. (2003). Gender differences in expectancy of academic success in mathematics (Unpublished Master's thesis). University of Wisconsin-Stout, Menomonie, USA.

Wieman, C. (2013). Science education initiative. Retrieved from http://www.cwsei.ubc.ca/resources/ files/Motivating-Learning_CWSEI.pdf
Williams, M., \& Burden, R. (1997). Psychology for language teachers: A social constructive approach. Cambridge, UK: Cambridge University Press.

Wong, B. S., \& Kang, L. (2012). Mastery learning in the context of university education. Journal of the NUS Teaching Academy, 2(4), 206-222.

Zimmerman, B. J., \& Dibenedetto, M. K. (2008). Mastery learning and assessment: Implications for students and teachers in an era of high-stakes testing. Psychology in the Schools, 45(3), 206-216. 